\title{
Research on the Legal Model of international Anti-Terrorism Coordination
}

\author{
Bozeng Wang ${ }^{1}$ \\ ${ }^{1}$ Beijing Normal University, Beijing, China \\ Correspondence: Bozeng Wang, Beijing Normal University, Beijing, China. E-mail: 18653669189@163.com
}

Received: October 21, 2020

Accepted: November 22, 2020

Online Published: November 23, 2020

doi:10.5539/ilr.v10n1p1

URL: https://doi.org/10.5539/ilr.v10n1p1

\begin{abstract}
Terrorism seriously endangers world peace and security. In order to achieve the goal of effectively combating international terrorism, we must promote the establishment of a multi-level model of anti-terrorism cooperation. The current legal models of international counter-terrorism cooperation mainly include global counter-terrorism cooperation, regional counter-terrorism cooperation and bilateral counter-terrorism cooperation.

Global counter-terrorism cooperation led by the United Nations is the most important form of counter-terrorism cooperation. The UN has set up a Counter-terrorism Committee and a series of treaties. The United Nations demands that States should prevent and stop the financing of terrorist ACTS; Criminalizes any person or thing that, by any means, directly or indirectly, provides or raises funds for terrorist activities; (b) Immediately freeze the assets of individuals and entities that facilitate, finance or participate in terrorist ACTS; The provision of any funds and financial assets and related services to individuals and entities assisting, financing or participating in terrorist ACTS is prohibited.

Regional counter-terrorism cooperation refers to the cooperation between geographically adjacent countries to combat terrorism, which is an important part of international counter-terrorism cooperation. The main regional anti-terrorism cooperation organizations are: Association of Southeast Asian Nations, South Asian Association for Regional Cooperation, European Union, Organization of American States, Shanghai Cooperation Organization.

Bilateral anti-terrorism cooperation refers to the cooperation between two parties in order to form a joint antiterrorism force. Bilateral cooperation can be between states or between states and regional organizations. Bilateral cooperation in flexible and diverse forms is also an important form of counter-terrorism cooperation.
\end{abstract}

Keywords: anti-terrorism coordination, regional anti-terrorism coordination, bilateral anti-terrorism coordination

\section{Introduction}

The current legal models of international anti-terrorism coordination mainly include global anti-terrorism coordination, regional anti-terrorism coordination and bilateral anti-terrorism coordination. In order to achieve the goal of effectively combating international terrorism, we must promote the establishment of a multi-level model of anti-terrorism coordination.

\section{Global Anti-Terrorism Coordination}

\subsection{The UN's Efforts in Global Anti-Terrorism}

\subsubsection{Promulgating the Global Anti-Terrorism Strategy}

On 8 September 2006, all 192 MEMBER States of the United Nations unanimously adopted the Global AntiTerrorism Strategy and formally launched it at a high-level meeting of the General Assembly on 19 September 2006. This marks the first time that countries around the world have agreed on a strategic plan in the field of antiterrorism. The Strategy strongly condemns terrorism in all its forms and manifestations, regardless of who it is committed by, where it occurs, and for what purpose, and proposes four measures to combat terrorism.

First, eliminate conditions conducive to the spread of terrorism. The main measures include: promoting the peaceful settlement of protracted conflicts by harnessing the capacity of the United Nations in conflict prevention, negotiation, mediation, the rule of law; Promote dialogue, tolerance and understanding among civilizations, cultures, ethnic groups and religions, promote mutual respect among religions, religious values, beliefs and cultures, and prevent defamation. 
Second, to prevent and combat terrorism. The main measures include not organizing, inciting, facilitating, participating in, financing, encouraging or tolerating terrorist activities and taking appropriate practical measures to ensure that their respective territories are not used by terrorist activities; Cooperate fully in the fight against terrorism to identify and bring to justice anyone who supports, facilitates, participates in or attempts to participate in the financing, planning, preparation or carrying out of terrorist ACTS or in providing safe havens; Make every effort to conclude and implement agreements on mutual judicial assistance and extradition and to strengthen coordination between law enforcement agencies to arrest and prosecute or extradite perpetrators of ACTS of terrorism; Strengthen coordination and coordination among States to combat crimes that may be linked to terrorism, including drug trafficking, illicit arms trade, money laundering, and the smuggling of nuclear, chemical, biological, radioactive and other potentially lethal materials; Encourage relevant regional and subregional organizations to create or strengthen anti-terrorism mechanisms or centres; Combating terrorism in all its forms and manifestations on the Internet; Strengthen national efforts and bilateral, subregional, regional and international coordination to improve border and customs controls in order to prevent and identify the movement of terrorists; To improve the security and protection of particularly vulnerable targets, such as infrastructure and public places, as well as response measures in the event of terrorist attacks and other disasters, in particular the protection of civilians.

Third, enhance the capacity of all countries to prevent and combat terrorism. The main measures include encouraging Member States to consider making voluntary contributions to United Nations anti-terrorism coordination and technical assistance projects; Exchange best practices in anti-terrorism capacity-building, using the framework provided by relevant international, regional and subregional organizations, and promote their contribution to the efforts of the international community in this regard; Hold regular informal meetings to enhance the communication and exchange of information among Member States, United Nations agencies dealing with anti-terrorism, relevant specialized agencies, relevant international, regional and subregional organizations and donors; Encourages the Anti-terrorism Committee and its Executive Board to continue to improve the consistency and efficiency of the provision of technical assistance in the field of anti-terrorism and to strengthen their dialogue with States and relevant international, regional and subregional organizations; Encourages the United Nations Office on Drugs and Crime, in close consultation with the Anti-terrorism Committee and its Executive Board, to strengthen its technical assistance to States in the implementation of international conventions and relevant resolutions on the prevention and suppression of terrorism; Encourages the International Monetary Fund, the World Bank, the United Nations Office on Drugs and Crime and the International Criminal Police Organization to strengthen their coordination with States; Encourages the International Atomic Energy Agency and the Organization for the Prohibition of Chemical Weapons, within their respective mandates, to continue their efforts to help States build capacities to prevent terrorists from acquiring nuclear, chemical or radioactive materials and to ensure the safety of relevant facilities; The United Nations is encouraged to cooperate with Member States and relevant international, regional and subregional organizations in identifying and exchanging best practices for the prevention of terrorist attacks on particularly vulnerable targets.

Fourth, ensure respect for human rights and the rule of law as the foundation of the fight against terrorism. The main measures include: protecting human rights and fundamental freedoms while combating terrorism; Any measures taken by States to combat terrorism are consistent with their obligations under international law, in particular human rights law, refugee law and international humanitarian law; States should actively become parties to and implement human rights law, refugee law and international humanitarian law; Developing and maintaining an effective national criminal justice system based on the rule of law; Reaffirming the important role of the United Nations system in promoting the rule of law, respect for human rights and the establishment of effective criminal justice systems.

\subsubsection{A Series of International Treaties and Resolutions on Anti-Terrorism Have Been Formulated}

Since the second half of the 20th century, the United Nations has established a series of international conventions on terror, including: "about prevention and punishment of violation shall be protected by international personnel crimes including diplomatic representative convention (on December 14, 1973), against the hostage-taking convention (on December 17, 1979), the international convention for the suppression of terrorist bombings (December 15, 1997), the international convention on severing financial aid to terrorism (on December 9, 1999), the international convention for the suppression of ACTS of nuclear terrorism (April 13, 2005).

Since 1999, the United Nations has adopted a series of anti-terrorism resolutions, including 1267(1999), 1333(2000), 1373 (2001), 1390(2002), 1452(2003), 1455(2003), 1526(2004), 1540 (2004), 1617(2005), 1699(2006), 1735(2006), 1822(2008) and 1904(2009). This paper briefly introduces the contents of Resolutions 1267,1333 and 1373. 
October 15, 1999, the United Nations Security Council adopted resolution 1267.It strongly condemns the use of Afghan territory, in particular Taliban-controlled areas, to harbour and train terrorists and plan terrorist ACTS, and reaffirms the vital importance of combating international terrorism for the maintenance of international peace and security; Require all States to refuse to take off or land on their territory any aircraft owned, leased or operated by or on behalf of the Taliban; Requires that all countries should be frozen designated funds and other financial resources, including by itself, or the Taliban are owned or controlled by the Taliban in the enterprise, owned directly or indirectly control of property derivatives or money, and to ensure that its own nationals or their borders to anyone, not for the benefit of the Taliban, or for the Taliban have indirect or direct control of any corporate benefit, to provide these or any other money or financial resources.

December 19, 2000, the United Nations Security Council adopted resolution 1333. The resolution article 8 paragraph c: all nations shall without delay to freeze Osama bin Laden and his related individuals and entities, including the "base" organization of capital and other financial assets, including by Osama bin Laden and his related individuals and entities have indirect or direct control of property derivatives or funds, and ensure that their citizens or their borders to anyone, not directly indirectly for Osama bin Laden, its affiliates or by Osama bin Laden and his related individuals and entities, including the "base" organization owned directly or indirectly control the interests of any entity, providing such or any other money or financial resources.

September 29, 2001, the United Nations Security Council adopted resolution 1373.The main contents are as follows :(1) states should prevent and stop the financing of terrorist ACTS; Criminalizes any person or thing that, by any means, directly or indirectly, provides or raises funds for terrorist activities; Immediately freeze the assets of individuals and entities that facilitate, finance or participate in terrorist ACTS; Prohibit the provision of any funds and financial assets and related services to individuals and entities that assist, finance or participate in terrorist ACTS; (2) States shall refrain from providing, either actively or passively, any form of support to entities or individuals involved in terrorist ACTS, including stopping the recruitment of members by terrorist groups and eliminating the supply of weapons to terrorists; Denying safe refuge to those involved in terrorist ACTS and preventing the use of national territory for terrorist activities; Identify terrorist ACTS as serious criminal offences in domestic legislation and ensure that anyone who funds, plans, prepares or commits terrorist ACTS or participates in the support of terrorist ACTS is brought to justice; To render mutual assistance to the maximum extent possible in criminal investigations or proceedings involving the financing or support of ACTS of terrorism, including assistance in obtaining evidence in the possession of the State necessary for the proceedings; Effective border control and control over the issuance of identity CARDS and travel documents and the movement of terrorists and terrorist groups by preventing the antifeiting, forgery or fraudulent use of identity CARDS and travel documents. (3) Active exchange of intelligence, in particular on the actions or movements of terrorists or networks; Forged or altered travel documents; Trafficking in arms, explosives or sensitive materials; The use of communications technology by terrorist groups; And the threat posed by the possession of weapons of mass destruction by terrorist groups.

\subsubsection{Establish an Anti-Terrorism Committee}

Under resolution 1373 (2001), the UN established a 15-member Anti-Terrorism Committee (CTC) to monitor the implementation of the resolution. In 2004, in order to revitalize the Work of the Commission, the Security Council adopted resolution 1535 (2004), establishing the Anti-terrorism Executive Board to provide expert advice to the Anti-terrorism Committee in all areas covered by resolution 1373 (2001).The main objective of the Commission is to provide technical assistance to States, to enhance their capacity to combat terrorism and to promote closer coordination and coordination within the organizations of the United Nations system as well as between regional and intergovernmental bodies. Since its establishment, the Committee has done a great deal of work in promoting international anti-terrorism and achieved remarkable results. First, compared with the number of countries that acceded to the international convention on anti-terrorism every year before the Committee was established, the number of countries that acceded to the convention has increased by 2-3 times. Second, more countries have ratified international anti-terrorism treaties. By December 2008, 102 countries were parties to all 12 instruments.

First, a series of visits to Member States. Series to promote the joint resolution to implement, since 2005 antiterrorism executive to represent national anti-terrorism committee access, assessment of member states to carry out the work of anti-terrorism situation, including the progress and the deficiency existing in priority areas, technical assistance needs, identify trends and challenges associated with terrorism and security council resolutions adopted in the implementation of the good practices. As of June 2018, more than 140 visits had been made to about 100 UN member States. These visits were conducted by experts from the Anti-terrorism Executive Board with the participation of international organizations and agencies such as the World Customs Organization, the European Union, the United Nations Office on Drugs and Crime, the International Civil Aviation Organization, the 
International Criminal Police Organization and the Financial Action Task Force on Money Laundering (FATF).

Second, strengthen dialogue with Member States. Since its inception, the Committee has worked to promote closer coordination and coordination within the United Nations system and among international, regional and subregional institutions in an ongoing dialogue with Member States.

Third, a special session will be convened. Since 2001, the Anti-Terrorism Committee has held six special meetings with international, regional and subregional organizations to discuss how best to cooperate with the Committee within the framework of global anti-terrorism efforts. The first meeting was held on 6 March 2003, with the participation of 60 organizations. It was agreed that international organizations would exchange relevant norms, standards and best practices within their mandates, that regional and subregional organizations would establish mechanisms to promote mutual assistance and coordination among neighbouring countries, and that countries would give high priority to anti-terrorism actions. The next five meetings were organized by the Organization of American States and its Inter-American Anti-terrorism Committee (Washington, October 2003); United Nations Office on Drugs and Crime and Organization for Security and Coordination in Europe (OSCE) (Vienna, March 2004); Commonwealth of Independent States (CIS) (Almaty, Kazakhstan, January 2005);African Union (Nairobi, October 2007);European Union (Sternesburg, April 2001). Under the auspices of the CTC, the G8, the World Bank and other international organizations have formulated anti-terrorism agendas and actively promoted anti-terrorism work in combination with their own functions.

\subsection{The Role of Other Universal International Organizations in Global Anti-Terrorism}

The International Civil Aviation Organization (ICAO), the International Maritime Organization (IMO), the International Atomic Energy Agency (IAEA) and the Universal Postal Union (UPU) also play an important role in promoting global anti-terrorism coordination. The International Civil Aviation Organization (ICAO), the International Maritime Organization (IMO), the International Atomic Energy Agency (IAEA) and the Universal Postal Union (UPU) are specialized agencies of the United Nations. These international organizations are independent in their organization and activities. They are not subsidiary organs of the United Nations, but only establish special legal relations with the United Nations in accordance with agreements.

\subsubsection{International Civil Aviation Organization}

On November 1, 1944, on December 7, 52 countries met in Chicago and signed the convention on international civil aviation (commonly known as the Chicago convention), establishing the provisional international civil aviation organization (ICAO). Since the 1950s, terrorist activities targeting civil aircraft, such as hijacking aircraft and destroying aviation facilities, have been increasing. In response to against the terrorist criminal activities of civil aircraft international aviation organization has to make the Tokyo convention, the Hague convention and the Montreal convention and the Montreal protocol, the international convention, in promoting national anti-terrorist coordination, to prevent and fight against civil aircraft has played an important role in terrorist activities.

\subsubsection{The International Maritime Organization}

The INTERNATIONAL Maritime Organization (IMO) is a Specialized United Nations agency responsible for the safety of maritime navigation and the prevention of Marine pollution from ships. For the prevention and strike on the ship and in ship ACTS of terrorism, the international maritime organization has formulated the "stop harming sea illegal convention (1988)," stop endangering maritime navigation safety protocol on illegal convention (2005), "stop the endanger of the continental shelf fixed platform security protocol on illegal behavior," stop the endanger of the continental shelf fixed platform security protocol 2005 illegal behavior protocol, the 1974 international safety of life at sea convention and amendment, the international ship and port facility security rules and other international documents, requires countries to cooperate actively, Concrete and effective measures shall be formulated and adopted to prevent all illegal ACTS endangering the safety of maritime navigation and the safety of fixed platforms on the continental shelf, and criminals shall be prosecuted and severely punished.

\subsubsection{International Atomic Energy Agency}

International Atomic Energy Agency (IAEA) is an agency that establishes relations with the United Nations and conducts scientific and technological coordination among governments around the world in the field of atomic energy. The INTERNATIONAL Atomic Energy Agency has formulated the Convention on the Physical Protection of Nuclear Material (1980), the Amendment to the Convention on the Specific Protection of Nuclear Material (2005),Calls upon States to take effective measures to ensure that nuclear materials and facilities are used for peaceful purposes;(b) Expand coordination in order to locate and recover stolen or smuggled nuclear material, mitigate the consequences of radiation or destruction, and prevent and combat related criminal ACTS; The unlawful possession, use, transfer or theft of nuclear material, as well as the threat of its use, resulting in death, 
serious injury or material property damage, are criminalized.

\subsubsection{Universal Postal Union}

The Universal Postal Union (UPU), referred to as the Universal Postal Union (UPU) or The Postal Union, is an inter-governmental organization that negotiates international Postal matters. Mail bomb is one of the commonly used means of attack by terrorists. Terrorists hide explosives in mail or packages and mail them to the destination, attacking the people receiving the packages to achieve the purpose of creating social panic. For example, in early 2007, there were seven consecutive mail bomb attacks in the UK, which injured nine people. In March 2018, six back-to-back parcel bombs exploded in the US state of Texas, injuring several people. In order to prevent, prohibit and punish the crime of illegal use of mail, on September 15, 1874, on October 9, representatives of 22 countries including Germany, Austria, Hungary and other countries held plenipotentiary congress in Bern, Switzerland, signed the first international postal convention, namely the treaty of Bern, and established the general postal union. In May 1878, the General Postal Union held its second congress in Paris, revised the Treaty of Bern and renamed it the Universal Postal Convention. The Convention prohibits the Posting of explosive, flammable and other dangerous articles.

\section{Regional Anti-Terrorism Coordination}

Regional anti-terrorism coordination refers to the coordination between geographically adjacent countries to combat terrorism, which is an important part of international anti-terrorism coordination.

\subsection{ASEAN}

The Association of Southeast Asian Nations (ASEAN) was established in Bangkok, Thailand, on August 8, 1967.It has 10 member states: Brunei Darussalam, Cambodia, Indonesia, Laos, Malaysia, Myanmar, Philippines, Singapore, Thailand and Vietnam. With a total area of about 4.49 million square kilometers and a population of 642 million (as of 2017). The secretariat is located in Jakarta, the capital of Indonesia.

\subsubsection{Anti-Terrorism Situation in the ASEAN Region}

Due to the prominent problems of ethnic and religious conflicts, there are many terrorist organizations in Southeast Asia and terrorist attacks happen from time to time. The influential terrorist organizations in ASEAN include Jemaah Islamiyah in Indonesia, ABU Sayyaf in the Philippines, Malaysian Armed Group in Malaysia, Pattani National Liberation Front and Pattani United Liberation Organization in Thailand, etc.

Jemaah Islamiah (Jemaah Islamiah) is one of the most influential terrorist organizations in Southeast Asia, with branches in Indonesia, Malaysia, Singapore, the Philippines and Thailand, aiming to establish a "Greater Islamic State" including Indonesia, Malaysia, the southern Philippines, Singapore and Brunei. On October 12, 2002, the group used car bombs to attack two night clubs on the Indonesian resort island of Bali, killing 202 people. In August 2003, Jemaah Islamiyah was also implicated in the bombing of the Marriott hotel in Jakarta, the capital, which killed 15 people, including four foreigners, and wounded 153 others.

"ABU Sayyaf Group" was established in the early 1990 s, is a southeast Asia of Islamic terrorist separatist groups, from the southern island of Mindanao some separatists called for an independent Islamic countries of violence, the Sulu archipelago, mainly concentrated in the southern Philippines Basilan and the islands of the island. The group engages in mass beheadings, kidnapping, extortion, illegal arms trading and drug dealing. ABU Sayyaf took 21 hostages, including Americans and other foreign tourists, from a Malaysian resort in April 2000, before the Philippine government defused the hostage crisis with a huge ransom of $\$ 20$ million. On May 27, 2001, ABU Sayyaf also kidnapped 20 tourists, including 13 Chinese Filipinos, three Americans and four hotel workers, from DOS Palmas on Palawan island. On November 5, 2014, ABU Sayyaf released a video boasting of the ransom (250 million Philippine pesos, or about 35 million yuan) paid for the recent release of two German hostages.

\subsubsection{ASEAN Anti-Terrorism Coordination}

First, a series of coordination documents have been issued. Since 2000, the association of south-east Asian nations (ASEAN) have issued the action plan for the association of south-east Asian nations (ASEAN) against transnational crimes (2002), the declaration of ASEAN joint anti-terrorism act (2011), the association of southeast Asian nations against terrorism convention (2017) and other documents, to strengthen coordination against terrorism, improving the capacity of preventing and cracking down on terrorism crimes provided the institutional framework, laid the basis of coordination.

Second, strengthen intelligence exchange and coordination. ASEAN countries attach great importance to intelligence coordination. In May 2002, Indonesia, Malaysia and the Philippines signed the Information Exchange and Information Processing Agreement. Since then, Cambodia, Thailand and Brunei have joined in succession. In 
May 2005, the intelligence database system was officially launched during the ASEAN National Police Chiefs' Meeting to strengthen the collection and exchange of information on terrorist organizations, terrorists, terrorist activities, terrorist funds and other aspects.

Third, strengthen joint law enforcement. We will actively carry out joint military exercises, joint patrols, joint law enforcement, criminal justice coordination and other activities. In 2017, the Philippines, Indonesia and Malaysia launched joint maritime patrol and joint air patrol mechanisms to strengthen coordination in combating regional terrorism and transnational crimes.

Fourth, strengthen security dialogue. We should facilitate security dialogue in the form of the ASEAN Regional Forum and the Ministerial Conference on Combating Transnational Crime, and strengthen coordination in the fight against terrorism, illicit drug trafficking, human trafficking, money laundering, piracy, arms smuggling, international economic crimes and cyber crimes.

\subsection{South Asian Association for Regional Coordination}

The South Asian Association for Regional Coordination (SAARC), founded on December 7, 1985, is a mutual assistance and Coordination organization jointly established by South Asian countries. As of January 2019, SAARC has eight member countries: Bangladesh, Bhutan, India, Maldives, Nepal, Pakistan, Sri Lanka and Afghanistan. The purpose of SAARC is to promote the well-being and improve the quality of life of the peoples of South Asia; Accelerate economic growth, social progress and cultural development in the region and provide everyone with the opportunity to live a decent life and realize their full potential; Promoting and strengthening collective self-reliance in South Asian countries; Promoting mutual trust and understanding and understanding of each other's problems; To promote active coordination and mutual support in the economic, social, cultural, technological and scientific fields; Strengthening coordination with other developing countries; Strengthen coordination on international occasions on issues of common interest. South Asia is the epicenter and hardest hit area of terrorist activities. Various kinds of terrorist activities occur frequently in South Asia. Promoting antiterrorism coordination among member states is an important task of SAARC.

\subsubsection{Situation in South Asia}

South Asia has one of the highest rates of terrorist attacks and deaths in the world, with India, Pakistan and Afghanistan among the worst hit countries. In 2009, South Asia accounted for 44 per cent of all terrorist attacks and 42 per cent of all deaths. In 2011, terrorist attacks caused 7,528 civilian casualties in Afghanistan, 2,738 in Pakistan and 429 in India. From 2002 to 2016, The terrorism index for Afghanistan, Pakistan and India was 9.4, 8.4 and 7.5, respectively; The growth rate reached $42 \%, 29 \%$ and $3 \%$ respectively; In 2017, the three countries were ranked second, fifth and eighth in the list of 10 countries most vulnerable to terrorism. Terrorism in South Asia has the following characteristics: First, religious extremist terrorism is serious. Most terrorist activities in South Asia are related to religious extremist terrorist organizations. Second, national separatism is prominent. Due to the large number of ethnic groups in South Asia, terrorist attacks triggered by ethnic conflicts and conflicts occur frequently. Third, it has strong links with drug cartels. The Taliban and AL Qaeda have become an important source of funding for terrorist organizations through the cultivation and trafficking of drugs.

\subsubsection{SAARC's Anti-Terrorism Coordination}

Due to the rampant terrorist activities in South Asia, countries attach great importance to anti-terrorism coordination. On 4 November 1987, SAARC member States signed the SAARC Convention against Terrorism, which stipulates that no State shall organize, incite, support or participate in terrorist activities by other States or acquiesce in such activities within its territory. In 2004, SAARC countries signed the Protocol Additional to the SAARC Convention on Combating Terrorism, calling for further deepening anti-terrorism coordination. In August 2008, at the 15th SAARC Summit, the Agreement on Mutual Assistance in Criminal Justice was adopted to enhance coordination in the tracking, arrest and transfer of terrorists.

However, due to the numerous conflicts among SAARC countries and the frequent occurrence of conflicts, SAARC's anti-terrorism coordination has been affected. It can be said that SAARC's anti-terrorism coordination has made little substantive progress. For example, the armed conflict in Kashmir between India and Pakistan, the two most important countries in South Asia, has almost never been interrupted, which will inevitably affect the coordination in all aspects including anti-terrorism coordination.

\subsection{The European Union}

In December 1991, the European Community Maastricht Summit adopted the Treaty on The European Union. On November 1, 1993, the treaty entered into force and the European Union was formally born. The European Union (EU), headquartered in Brussels, Belgium, grew out of the European Community. There are six founding members, 
namely, Germany, France, Italy, the Netherlands, Belgium and Luxembourg. The alliance now has 28 member states and 24 official languages. The European Union is the largest international organization of regional economic coordination in the European region. Its objectives are to promote peace, pursue a prosperous life for citizens, achieve sustainable socio-economic development, ensure basic values and strengthen international coordination. The EU countries are not only frequent terrorist attacks, but also important bases for terrorist organizations to recruit, train personnel and raise funds. Promoting anti-terrorism coordination is one of the EU's important tasks.

\subsubsection{Anti-Terrorism Situation in the European Union}

After the "9.11 Attack", Europe was faced with the serious terrorist threat, and a series of terrorist attacks took place in succession, which shocked the world, and Europe has become one of the regions most seriously threatened by terrorism in the world. At about 7:40 a.m. on March 11, 2004, a series of explosions ripped through four suburban passenger trains in Madrid, killing 192 people and injuring more than 1,500. It was the deadliest massacre in Madrid's history. Suicide bombings on three London underground trains and a bus during the morning rush hour on July 7, 2005, killed 52 passengers and injured more than 700. At least 132 people were killed in a series of terrorist attacks in Paris on the night of November 13, 2015.

\subsubsection{EU Anti-Terrorism Coordination}

First, we issued a series of documents on anti-terrorism coordination. In order to strengthen coordination against terrorism, the EU has issued the anti-terrorism action plan (September 2001), "the decision of the framework of the fight against terrorism" (June 2002), the declaration of combating terrorism (March 2004), the European Union anti-terrorism strategy (December 2005), and other files, in order to strengthen anti-terrorism coordination laid a solid foundation.

Second, we have strengthened anti-terrorism coordination measures. The EU Anti-Terrorism Strategy, launched in 2005, identified the four pillars of EU anti-terrorism: prevention, protection, capture and response. The main preventive measures include: strengthening dialogue and exchanges with different civilizations; Assistance to developing countries; We will strengthen the integration of diplomacy, security and defense. In terms of protection, the main measures are as follows: strengthening safety protection measures for key targets such as nuclear power plants, power networks, aviation, roads and water transportation; Strengthening police coordination and visa coordination based on the Schengen Agreement to prevent cross-border movement of terrorists; Prevent the proliferation of weapons of mass destruction and so on. Implementation of the European Uniform Arrest warrant and European Search warrant for Evidence system; Promoting mutual recognition of judicial decisions among Member States; Strengthen the exchange of intelligence information. The main antimeasures include: improving the rapid response capability of the anti-terrorist forces; Improve emergency measures and plans; Providing assistance to victims of terrorist attacks, etc.

\subsection{Organization of American States}

As a regional international organization consisting of the United States and Latin American countries, formerly known as the League of American Republics. It was founded on April 14, 1890 and renamed to its present name at the 9th Pan American Congress held in Bogota in 1948. At present, the organization has 33 member states, and 58 countries or regions from Europe, America, Asia and Africa have permanent observers in the Organization. The ORGANIZATION of American States was formerly known as the Union of Continental Republics. From October 1889 to April 1890, the United States and 17 Latin American countries held the first International Conference of the Americas in Washington, D.C. On April 14, the United States established the International League of American Republics and its permanent body, the Bureau of Commerce of the American Republic. The purpose of the Organization is to strengthen peace and security on the continent; Guaranteeing the peaceful settlement of disputes between member States; To organize ACTS of solidarity in the event of aggression against member States; To seek solutions to political, economic and legal problems among the Member States and to promote economic, social and cultural coordination among them; Control of conventional weapons; Accelerate the integration of The Americas.

\subsubsection{Anti-Terrorism Situation in the Americas}

Terrorist activities in the Americas are concentrated in the triangle between Colombia, Argentina, Brazil and Paraguay. Terrorist activities occur frequently in Colombia. The main terrorist organizations are: "Revolutionary Armed Forces of Colombia", "National Liberation Army", "United Self-defense Forces of Colombia" and so on. The triangle between Argentina, Brazil and Paraguay is a hotbed of "sleeper" terrorists because of its mixed population, smuggling, money laundering, drug trafficking and arms trafficking. 


\subsubsection{Anti-Terrorist Coordination in the Organization of American States}

First, a number of coordination documents have been issued. In 1971, the Organization of American States adopted the Convention on the Prevention and Punishment of Terrorist Activities, which defined terrorist crimes as international crimes and excluded them from political crimes. In June 2002, the Inter-American Convention on Terrorism was adopted, which identified terrorism as a serious threat to the Americas and called on all countries to make joint efforts to combat terrorism.

Second, we need to strengthen coordination. The OAS member states actively carry out coordination in the areas of arrest, extradition and intelligence to make the fight against terrorism more effective. The United States plays an important role in coordination. Through economic assistance and training of anti-terrorism personnel, the United States helps other countries enhance their anti-terrorism capabilities and intensify its efforts.

\subsection{The African Union}

The African Union (AU) is a union of 55 African member states. It is a political entity with an African character, integrating politics, economy and military. The African Union grew out of the Organization of African Unity, which was established on 25 May 1963. In July 2001, the 37th OAU Summit decided to formalize the transition to the AU. On 8 July 2002, the OAU convened its last summit in Durban, South Africa.9 solstice 10, the African union held its first summit, and announced the establishment of the African union, the African union officially replaced the OAU. It is headquartered in Addis Ababa, Ethiopia. The purpose of the Organization is the sovereign equality and interdependence of its member states. Respect the boundaries that existed at the time of independence; Peaceful coexistence; Non-interference in internal affairs; Developing a common defense policy; Peaceful settlement of disputes, prohibition of the use or threat of force; Respect for democratic principles, human rights, the rule of law and good governance; Respecting the sanctity of human life, condemning and opposing assassinations, ACTS of terrorism and subversive activities; Let the African people widely participate in the building of the $\mathrm{Au}$; To oppose the unconstitutional change of the regime; In the event of war crimes, genocide or large-scale humanitarian crises among its member states, the $\mathrm{AU}$ has the right to intervene as the General Assembly decides; To restore peace and security, member States have the right to request AU intervention; Promoting gender equality; We will promote social justice and balanced economic development.

\subsubsection{The Anti-Terrorism Situation Facing the African Union}

In recent years, terrorism has become increasingly active on the African continent. There are mainly four regions under the threat of terrorism in Africa: the region around Somalia, the North African region, the Lake Chad region and the Sahel region. The Sahel, for example, has become a hotbed of extremism because of instability, war, poverty and uneven development. In a decade, extremism has killed 20,000 people in the region and displaced 3.5 million. The main terrorist groups in Africa are al-Qaida in the Islamic Maghreb (AQIM), Boko Haram, Al-Shabab in Somalia, the Lord's Resistance Army, Islamic extremist groups in Egypt, and pirates in the Gulf of Aden and Gulf of Guinea. The main goal of these terrorist groups is to create an independent Islamic State by waging jihad, overthrowing their governments, expelling Western powers and influence, and enforcing strict Islamic law.

\subsubsection{Anti-Terrorism Coordination of the African Union}

The AU attaches great importance to anti-terrorism and actively promotes multi-tiered anti-terrorism coordination. (such as: in 2015, five African countries, Nigeria, Cameroon, Chad, Niger and Benin) under the international community to help 8700 people formed a coalition forces, "Boko Haram" controlled area by multiple operations, to recover the occupied land, destroyed the material base there existing in the terrorist organization, forcing its residual strength gone underground. However, due to the numerous conflicts and lack of mutual trust among African countries, anti-terrorism coordination faces many challenges and still needs to be actively promoted.

\subsection{League of Arab States}

The League of Arab States is a regional international organization established to strengthen unity and coordination among Arab States. It is the earliest regional organization in the world. The Arab League or the Arab League for short. In September 1944, at the initiative of Egypt, the Arab Foreign Ministers met in Alexandria to draw up the Alexandria Protocol and decided to establish the League of Arab States. The organization's purpose is close relations of coordination between member states, coordinate each other's political activities, defend the independence and sovereignty of Arab countries to promote the overall interests of Arab countries, and promote the member states in economic, finance, transportation, culture, health, social welfare, nationality, passport, visa, judicial close coordination. The member States respect each other's political systems, disputes between them shall not be settled by force, and treaties and agreements concluded between one Member state and other States shall not be binding on the other member States. 


\subsubsection{The Anti-Terrorism Situation Facing the Arab League}

In the Arab region, Arab countries once swept by the "Arab Spring" movement, such as Tunisia, Egypt, Libya, Yemen and other Arab countries, due to political instability, are more seriously threatened by terrorism. On 18 March 2015, 23 people, including three Tunisians and 20 foreign tourists, were killed in an armed attack and hostage-taking at the Bardo Museum near the country's parliament building. On March 20, 2015, suicide bombings at two Shiite mosques in Yemen killed more than 150 people. On June 26, 38 people were killed in a terrorist attack on a hotel in the coastal resort city of Sousse. On January 7, 2016, members of the Libyan branch of the Islamic State drove an oil tanker into a police training camp in the coastal city of Zlitan and detonated a bomb, killing more than 50 people on the spot and injuring more than 100 others.

\subsubsection{Anti-Terrorism Coordination of the Arab League}

On July 25, 2016, the 27th Summit of the League of Arab States (Arab League) opened in Nouakchott, capital of Mauritania. The two-day meeting was devoted to anti-terrorism. The meeting called on member states of the Arab League to promote broader coordination and intensify efforts to combat terrorism. Members have also actively cooperated in freezing and confiscating property related to terrorist activities, exchanging anti-terrorism intelligence and extraditing terrorist criminals to each other.

\subsection{The Shanghai Coordination Organization}

The Shanghai Coordination Organization (SCO) is a permanent inter-governmental international organization established on 15 June 2001 in Shanghai, China, by the People's Republic of China, the Republic of Kazakhstan, the Republic of Kyrgyzstan, the Russian Federation, the Republic of Tajikistan and the Republic of Uzbekistan. In July 2015, India and Pakistan joined the SCO. At present, the Shanghai Coordination Organization has become a trans-regional and multilateral comprehensive organization with the largest population, the largest geographical area and great potential, making important contributions to safeguarding regional security and stability and promoting common development and prosperity. The objectives of the SCO are to strengthen mutual trust and good-neighbourly relations among its member states; To encourage effective coordination among the Member States in the political, economic, scientific, technological, cultural, educational, energy, transportation, environmental protection and other fields; Jointly committed to maintaining and safeguarding regional peace, security and stability; Establish a new international political and economic order that is democratic, just and reasonable. The SCO holds formal talks between heads of state and heads of government on a regular basis in turn among its member states.

\subsubsection{The Anti-Terrorist Situation Facing the SCO}

The member states of the Shanghai Coordination Organisation are also facing serious terrorist threats. Since the 1990s and the beginning of the independence of the five central Asian states, the "three forces" began to spread in the region and violent terrorist incidents occurred from time to time. On March 29, 2010, at least 38 people were killed and 63 injured in a series of suicide bombings at the Lubyanka and Park Kultury metro stations in central Moscow. On August 24, 2004, a Russian Volga Express Tu-134 airliner crashed in Tula and a Siberian Air Tu-154 crashed in Rostov prefecture. The two crashes killed a total of 90 people. China is also facing a serious threat from the forces of Tibetan independence and Xinjiang independence, and serious terrorist incidents have occurred many times.

\subsubsection{Coordination in the Fight against Terrorism in the SCO}

The SCO attaches great importance to anti-terrorism coordination and has achieved remarkable results. According to statistics, from 2013 to 2017, the SCO member states agencies were to stop 600 cases with characteristics of terrorism crime, training base, destroyed more than 500 militants captured more than 2000 members of the international terrorist organizations, seized more than 1000 pieces of homemade explosives, more than 50 tons of explosives, more than 10000 guns and 100 rounds of ammunition. Between 2016 and 2017, member states blocked more than 100,000 websites that contained more than 4 million messages promoting terrorism and extremism.

First, a series of legal documents have been issued. Since its establishment, the formal SCO has signed "the fight against terrorism, separatism and extremism Shanghai convention (2001), the SCO anti-terrorism convention (2009), the Shanghai coordination organization (SCO) against extremism convention (2009), the Shanghai coordination organization (SCO) member states about regional anti-terrorism agency agreement", "about the organization in the Shanghai coordination organization (SCO), and held a joint anti-terrorism action program agreement", "about to find out and cut off in the Shanghai coordination organization (SCO) member states to participate in the activities of terrorism, separatism and extremism personnel seepage channel agreement and other documents, It laid an institutional foundation for anti-terrorism coordination. 
Second, we will set up a specialized agency for combating terrorism. On 7 June 2002, the heads of the SCO member states signed in St. Petersburg the Agreement of the SCO Member States on a Regional Anti-terrorism structure, and decided to establish a regional anti-terrorism structure of the SCO, with its headquarters in Bishkek, Kyrgyz Republic. In 2004, the regional anti-terrorism agency was officially launched in Tashkent. The main functions of the Organization are to maintain working contacts with the relevant agencies of member States and international organizations responsible for combating terrorism, separatism and extremism;(c) Strengthen collaboration among Member States in the preparation and conduct of anti-terrorism exercises, as well as in the preparation and conduct of arrest and other operations against terrorism, separatism and extremism at the request of the Member States concerned; To participate in the preparation of draft international legal documents dealing with the fight against terrorism, separatism and extremism; Collect and analyse information obtained by antiterrorism agencies from member States, establish and supplement a database of anti-terrorism agencies; Participating in the establishment of effective mechanisms to address global challenges and threats; To prepare and hold academic conferences, seminars and assist in the exchange of information on the fight against terrorism, separatism and extremism.

Third, we need to strengthen coordination. First, we will carry out joint anti-terrorism military exercises. Since 2005 , the SCO has held a joint military exercise every year with the aim of dealing with non-traditional security threats facing all countries and not targeting any country. Second, actively carry out coordination in intelligence, justice and other fields to constantly enhance the joint effort in fighting terrorism.

\section{Bilateral Coordination}

Bilateral anti-terrorism coordination refers to the coordination between two parties in order to form a joint antiterrorism force. Bilateral coordination can be between states or between states and regional organizations.

\subsection{Coordination between the United States and the European Union}

\subsubsection{A Series of Coordination Agreements Have Been Reached}

After the "9.11" incident, in order to jointly deal with the terrorist threat, the United States and the European Union successively reached a series of anti-terrorism coordination agreements. In 2001 and 2002, the United States and Europol signed agreements allowing U.S. law enforcement agencies and Europol to share strategic information (risk assessment, threat alerts, crime patterns) and personal information (names, addresses, criminal records, etc.); In February 2010, the AGREEMENT between the United States and Europe on extradition and judicial assistance came into force.

\subsubsection{Main Measures for Coordination}

First, intelligence information sharing. The US and Europe attach great importance to intelligence information sharing and have reached SWIFT agreement and PNR agreement. The SWIFT agreement gives the US access to data from Belgium-based international syndicated Banks, while the PNR agreement allows US authorities to access the personal booking information of EU air passengers as well as passenger information 15 minutes before their flight takes off. Second, air transport security coordination. In June 2012, the United States and the European Union reached a coordination agreement on air transport security, in which the two sides recognized each other's air transport security system and required different security schemes for flights to different destinations. Third, maritime transport safety coordination. In April 2004, the United States and the European Union signed a customs coordination agreement that requires the United States to assist in the inspection of container cargoes to ensure that ships are not carrying explosive hazardous materials. Fourth, visa coordination. The United States and Member states of the European Union are actively promoting visa-free entry. But the US requires travelers entering the country without a visa to enter their personal biometric information two days in advance via the ESTA system, which compares their biometric information with information from a database of law enforcement information. Those with no problems are exempt.

\subsection{Coordination between the United States and Pakistan}

Since Pakistan shares a direct border with Afghanistan, the two countries have a long border. After the "9.11" incident, the United States attaches great importance to coordination with Pakistan and takes Pakistan as a nonNATO ally in global anti-terrorism, which has achieved remarkable results.

\subsubsection{Strengthening Intelligence Coordination}

The CIA and Pakistan's Inter-Services Intelligence (ISI) have set up intelligence-sharing mechanisms. It was through effective intelligence coordination that we successively captured terrorist leaders such as Bin Laden, Khalid Al-Atash and Ramaz bin Al-Shabab, dealing a heavy blow to AL Qaeda. 


\subsubsection{The United States Increased Its Assistance}

Through antiterrorism coordination, the United States provides billions of dollars in aid to Pakistan. The United States has also sent trainers to Pakistan to help train the army and police to improve anti-terrorism capabilities.

\subsection{Coordination between China and Russia}

As China and Russia are neighboring countries and face the threat of the "three evil forces", the two countries attach great importance to bilateral anti-terrorism coordination.

\subsubsection{Signing of Coordination Documents}

On September 27, 2010, China and Russia signed the Agreement on Coordination between the Russian Federation and the People's Republic of China on Combating Terrorism, Separatism and Extremism. Approved by the Standing Committee of the National People's Congress in December 2011; In November 2016, the Russian State Duma approved. According to the agreement, the two countries will share preventing and cracking down on terrorism, separatism and extremism crime information, including the illegal manufacture, possession and selling promotional materials, weapons, ammunition and explosives, crime organization financing sources, channels, and they could use nuclear materials and toxic substances such as planning of information; The two sides hold regular meetings and consultations and carry out joint operations in the border areas; Actively carrying out criminal cases to assist in investigation.

\subsubsection{Conducting Joint Anti-Terrorism Exercises}

In order to enhance operational skills, explore new forms and methods of joint operations, and improve the effectiveness of joint anti-terrorism operations, China and Russia have conducted several joint anti-terrorism exercises, including "coordination-2007", "coordination-2013", "coordination-2016", "coordination-2017" and "coordination-2019".

\subsubsection{Establish a China-Russia Anti-Terrorism Working Group}

In 2001, China and Russia set up an anti-terrorism working group and held regular meetings. On November 28 solstice 29, 2001, the first meeting of the Russia-China anti-terrorism working group was held in Beijing. The two sides agreed that the fight against terrorism is a systematic and long-term effort. Coordination among States in this field should be based on the CHARTER of the United Nations and other norms of international law, and extensive anti-terrorism measures should be adopted. The two sides reaffirmed that terrorism threatens international and regional peace and security and affects world economic development. The two sides stressed that terrorism should not be equated with a particular religion, nation or civilization, nor should double standards be applied on antiterrorism. The two sides expressed their willingness to cooperate and support each other to combat terrorism in all its forms, wherever it occurs and by whom.

\section{References}

Dai, B., \& Tu, L. D. (2018). Counter-terrorism Situation and Prospect in the Arab region. Country and Regional Studies, (1).

Li, J. X. (2012). Evaluation of Governance Model of THE United Nations Counter-terrorism Committee. International Security Studies, (6).

Ma, Y., \& Qiu, S. (2013). The Trend of Terrorism and Counter-terrorism Cooperation in South Asia. International Research Reference, (1).

Shen, Z. H., \& Su, R. L. (2015). Analysis of the European Union's Anti-Terrorism Policy in the post-9/11 Era. International Forum, (4).

Wang, L., \& Liu, H. B. (2015). US-EU Anti-Terrorism Cooperation and Enlightenment. Public Security Education, (7).

Zhang, J. D. (2007). Terrorism and its Governance in the Era of globalization. Shanghai: Shanghai Sanlian Bookstore.

Zhou, L. (2011). Evolution and Development of ASEAN Regional Anti-Terrorism Cooperation Mechanism. Southeast Asia Crisscross, (3). 


\section{Copyrights}

Copyright for this article is retained by the author(s), with first publication rights granted to the journal.

This is an open-access article distributed under the terms and conditions of the Creative Commons Attribution license (http://creativecommons.org/licenses/by/4.0/). 